owners have three options: they may continue maintaining regulatory authorizations themselves, sign an arbitrated agreement to share responsibility with other companies, or discontinue maintenance by either transferring responsibility to another company or, failing that, announcing their intention to discontinue filing seven years hence.

Although it sounds straightforward, representatives from the companies and industry organizations have been gathering since 2010 for weekly meetings, sometimes several days long, to outline the legal framework for the 38-page document. "It's been a long journey," says Matt O'Mara, director of international affairs at BIO.

O'Mara believes that at the end of most patents' lives, consortiums will form to cover the costs of maintaining approvals. So far, however, the only signatories include seed giants, BASF Plant Science of Raleigh, North Carolina, Bayer CropScience in Monheim, Germany, Indianapolis' Dow AgroSciences, DuPont Pioneer of Johnston, Iowa, and Monsanto. None of the smaller seed companies have joined. Enright remains hopeful. "If you look at the signatories in six months, I think you're going to see new names."

Whereas GEMAA covers half the framework necessary for maintaining approvals, the signatories are now working on a second agreement called the Data Use and Compensation Agreement (DUCA) to be completed in 2013. Companies must periodically submit new data in order to maintain international approvals on crops that combine several foreign genes, or gene stacks. For gene stacks in Europe, for example, companies must submit data on the foreign genes in all their permutations. Therefore, as the number of genes in stacks rise, these data packages become exponentially larger and more expensive to maintain. With 100 pages written so far, the accord specifies that DUCA mandate signatories to share their data in return for managing the data, for which they will collect a designated fee. "We've got to make sure in the post-patent environment that someone is answering the phone calls from regulators, or trade is going to stop," says O'Mara.

Of the stacked seeds on the market, about half are the result of cross-licensing between companies. Monsanto's Smartstax corn, for example, incorporates an insect protection gene from Dow (Herculex Xtra), an herbicide resistance gene from Bayer (LibertyLink) and its own glyphosate resistance gene in Roundup Ready 2. DUCA will ensure that a single gene going off patent won't jeopardize the other licenses in a stacked product. "Cross-licensing is the lifeblood of the seed breeding industry," O'Mara says.

The accord emerged out of a morass surrounding Monsanto in 2009-2010, when it first commercialized Roundup Ready 2 . The company became embroiled in a legal battle with DuPont over DuPont's program to stack the Roundup Ready 2 gene with DuPont's own glyphosate resistance gene. Monsanto sued for patent infringement. DuPont countered with an antitrust suit that prompted the US Department of Justice and a number of state's attorneys to begin their own antitrust investigations. "There was a lot of confusion at that time. I think a lot of competitive pressure and actions were causing some of that confusion," says Monsanto's Steiner.

Those allegations have since faded. A Missouri judge awarded Monsanto $\$ 1$ billion in its suit. And DuPont's antitrust suit, which will go before the same judge next year, will likely fail, according to legal experts. "It's just gone away after they did the dog and pony show," says Tamara Nelsen, senior director of commodities at the Illinois Agricultural Association in Bloomington, Illinois.

After patent expiration, with GEMAA in place, the seed companies that now license Roundup will have one less bill to pay. "We still have some 600 small seed companies in the US. What we expect some of those smaller companies to do is look for more of a niche," says Nelsen. For smaller farms without the ideal farming conditions, "you are not going to worry about buying the latest and greatest."

At stake is the question, with a majority market share in most of America's staple crops, is Monsanto stifling competition and a potential generics market? "Ninety-three percent of soybean production is Roundup Ready," says Nelsen. "It's still like everyone is on a Microsoft system-at least, that's how farmers feel."

Daniel Grushkin, Brooklyn, New York
IN brief

\section{Banking iPS cells}

Ten pharma companies led by Roche of Basel are to set up a human induced pluripotent stem (iPS) cell bank in collaboration with 23 academic groups coordinated by Zameel Cader, of the Stem Cell Institute at Oxford University. The €55.6 (\$72)-million project known as StemBANCC is part of Europe's public-private Innovative Medicines Initiative (IMI). At the same time, the UK will launch a national iPS cell bank, Human Induced Pluripotent Stem Cell Initiative (HIPSCI), with $£ 12.75$ (\$20.5) million in funding from the Medical Research Council and the research charity Wellcome Trust. Both projects aim to develop standardized, genetically defined iPS cell lines and protocols for use as research tools. The biopharma industry has recognized the value of using iPS cells for high-throughput screening, toxicity testing and disease research, but views the generation of cell lines as precompetitive work. The IMI, whose brief is to improve the environment for pharma research in Europe, decided to set up a panEuropean iPS cell repository after assessing the situation in the US. There, many small, privately funded cell banks, struggle to be viable despite an exponential increase in stem cell research such that demand outstrips supply. This points to a "unique opportunity," according to an IMI document, to create an industrial-scale, not-for-profit cell bank that will act as a panEuropean storage and distribution center for iPS cells. The StemBANCC aims to generate 1,500 standardized, genetically defined iPS cell lines from 500 patients to develop models to study a range of diseases. It has a business plan to become self-financing in the next six years. The UK's national iPS cell bank HIPSCI aims to generate iPS cells from over 500 healthy individuals and 500 people with genetic disease. The goal is to use these cells to study the effects of genomic variation on cellular phenotypes. The aim of both projects is to standardize protocols for differentiating iPS cells to specialized cell types; neither mention potential clinical applications of the cells themselves. However, Keith Thompson, CEO of the UK's national Cell Therapy Catapult Centre, said that advancing the use of iPS cells as tools will also "inform strategies around the development of therapies." The UK national stem cell resource project will be led by King's College London and the Hinxton, Cambridge-based Wellcome Trust Sanger Centre.

Nuala Moran

\section{IN their words}

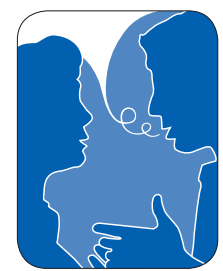

"Science is politics and the politics of amyloid won," says Claude Wiischik, founder of TauRx Pharmaceuticals, of Aberdeen, UK, whose company works on an alternative hypothesis that tau tangles drive

Alzheimer's disease. (The Wall Street Journal, 9 November 2012.) 